\title{
A NEW CHEMICAL STRAIN OF CLADONIA FURCATA (HUDS.) SCHRAD. (LICHENES)
}

\section{A. BARENDREGT, P. J. L. VAN DEN DRIES and H. J. M. SIPMAN}

Instituut voor Systematische Plantkunde, Heidelberglaan 2, 3584 CS Utrecht

The well-known and widespread lichen species Cladonia furcata (Huds.) Schrad. is usually very constant in its chemistry: fumarprotocetraric acid is its main secundary metabolite, sometimes accompanied by atranorin. Recently a new chemical strain, characterised by the presence of psoromic acid instead of fumarprotocetraric acid or atranorin, was found in Portugal by the first two authors during phytosociological investigations of heath vegetations. The plants are preserved in the herbarium of the Institute of Systematic Botany, University of Utrecht (U), leg. Barendregt \& v.d. Dries nr. 1-2 (U).

Morphologically the plants with psoromic acid represent the slender form of $C$. furcata, which is the predominant form in lowland western Europe (fig. I). The podetia are $\mathrm{c.} 3 \mathrm{~cm}$ long and up to $0.8 \mathrm{~mm}$ wide, branching regularly

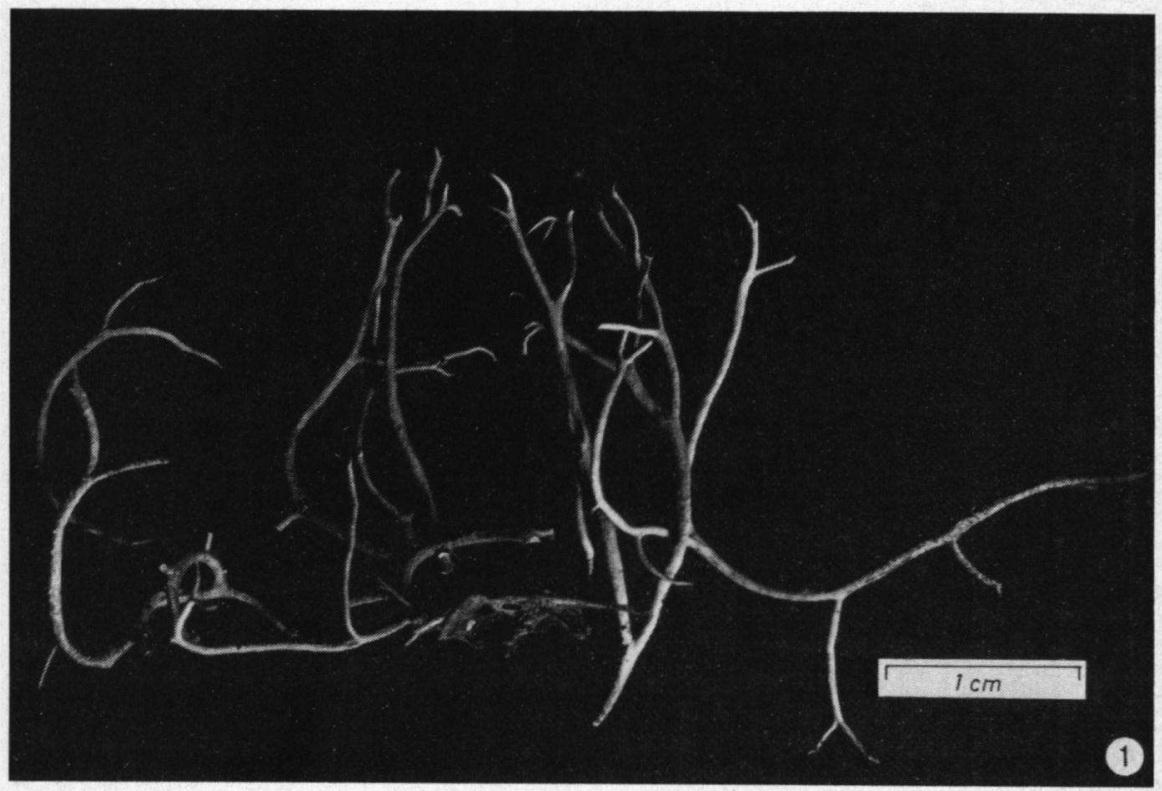

Fig. 1. (Huds.) Schrad. Plant with psoromic acid, from Penhas Douradas, Portugal, leg. Barendregt \& v.d. Dries nr. 1 (U). 
but not very densily dichotomously, and olivaceous green to brownish in colour. Their habit varies from creeping and loosely tufted to erect and densily tufted. Squamules are present only occasionally, on the lower parts of the podetia, and are roundish with a crenulated margin, up to c. $1.2 \mathrm{~mm}$ wide.

The slender form was treated as a distinct variety by SANDSTEDE (e.g. 1931): C. furcata var. racemosa (Hoffm.) Flk., which name was corrected by THOMSON (1967) into $C$. furcata var. furcata. It is usually very distinct from $C$. furcata var. pinnata (Flk.) Vain., the commonest form in the central european mountain areas, which has much thicker podetia with more numerous and larger squamules.

The specimens with psoromic acid lack apothecia, and only a few podetia bear pycnidia on the tips. Consequently longitudinal fissures are nearly absent. No morphological differences between the plants with aberrant chemistry and those with the usual chemistry from the same localities could be observed.

The presence of psoromic acid was indicated by the yellow colour reaction upon application of paraphenylene diamine solution, and checked by TLC (WALKER \& JAMES 1980, solvent system A). No trace of atranorin or fumarprotocetraric acid was found.

The new chemical strain of Cladonia furcata was found in six phytosociological relevés (fig. 2). One was made in the Serra de Montemuro (Serra de Bigorne) near Carvalhosa $\left(7^{\circ} 56^{\prime} \mathrm{W}, 40^{\circ} 57^{\prime} \mathrm{N}\right)$ at an altitude of c. $1100 \mathrm{~m}$. The five other relevés were in the northern parts of the Serra da Estrela in the surroundings of Penhas Douradas $\left(7^{\circ} 32^{\prime} \mathrm{W}, 40^{\circ} 25^{\prime} \mathrm{N}\right.$ to $\left.7^{\circ} 35^{\prime} \mathrm{W}, 40^{\circ} 24^{\prime} \mathrm{N}\right)$ at 1300 to 1525 $\mathrm{m}$. All localities are situated in the higher parts of the mountains, on windy, rocky places with a severe climate. Soils are $5-40 \mathrm{~cm}$ deep and consist of humous or sandy material with gravel, mostly on granite. pH-Values are between 4.7 and 5.0 .

The vegetation of the plots can be characterised as an open heathland vegetation, 25-50 cm high. It shows characters of both Ericion umbellatae and Juniperion nanae and resembles the Junipero-Ericetum aragonensis (BRAUN-BLANQUET et al. 1964). Frequent species are Halimium alyssoides, Erica australis and $E$. umbellata, accompanied by e.g. Agrostis delicatula, Sedum brevifolium and Lotus corniculatus. Codominant in one or two relevés each are Calluna vulgaris, Chamaespartium tridentatum, Echinospartum lusitanicum and Ulex europaeus. Cryptogams are very abundant, mostly with cover percentages of $10 \%$, and showing a high diversity. The following species were listed from the six relevés: the mosses Bartramia pomiformis, Campylopus flexuosus, C. pilifer, Ceratodon purpureus, Dicranum scoparium, Grimmia trichophylla, Hypnum jutlandicum, Pleuridium acuminatum, Polytrichum juniperinum, $P$. piliferum, Racomitrium canescens, $\boldsymbol{R}$. heterostichum, and the lichens Cladonia arbuscula, C. bacillaris, C. cervicornis, C. chlorophaea, C. coccifera, C. fimbriata, C. floerkeana, C. macilenta, Coelocaulon aculeatum, Hypogymnia physodes, Peltigera rufescens and Sphaerophorus globosus.

The discovery of a strain with psoromic acid in Cladonia furcata is an indication of the limited taxonomic value of a replacement of fumarprotocetraric acid 


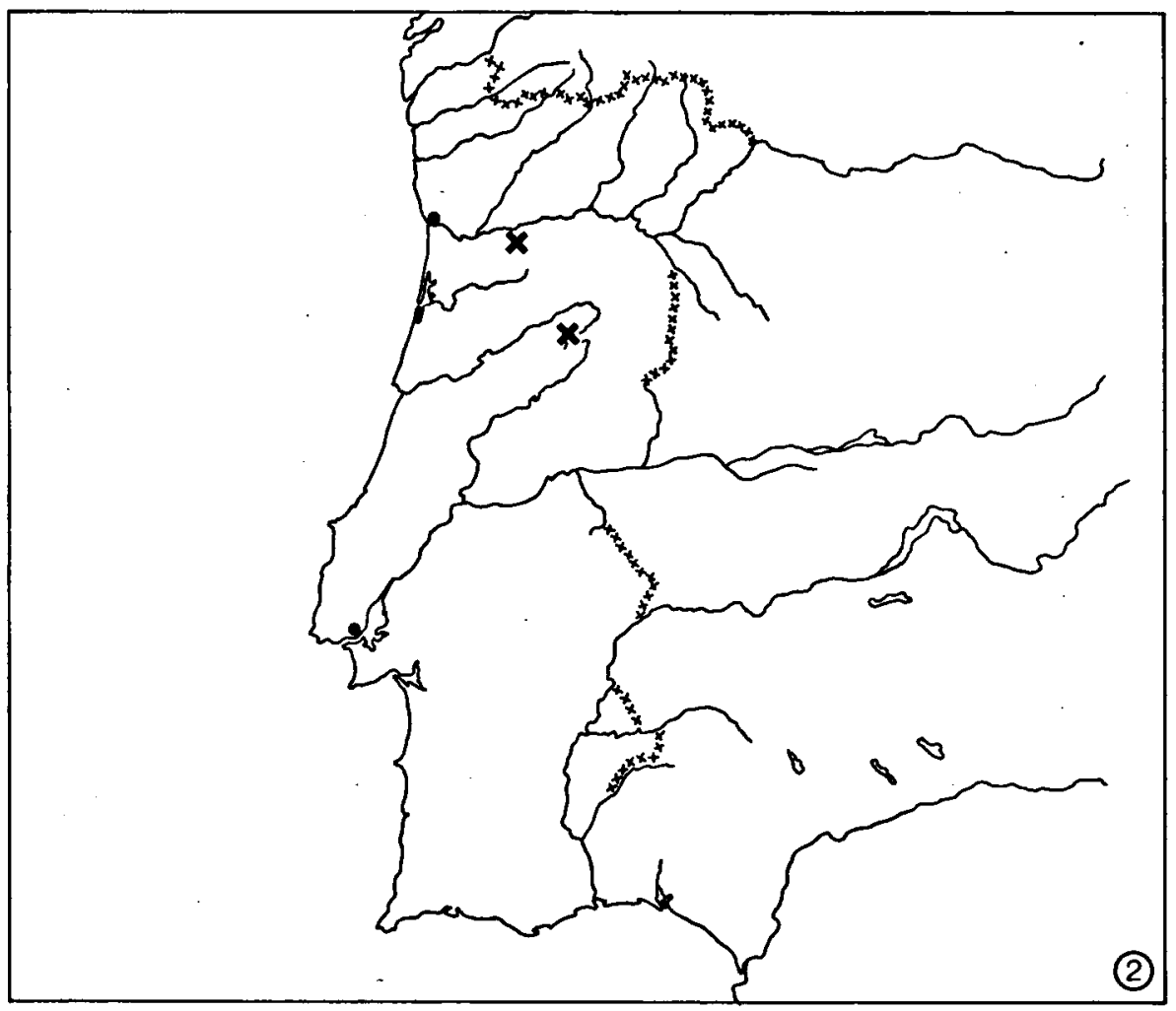

Fig. 2. Map of Portugal. The crosses mark the localities where plants of Cladonia furcata (Huds.) Schrad. with psoromic acid were found.

by psoromic acid. This may have consequences for the taxonomic position of Cladonia rappii Evans, or the C. cariosa-group. Moreover it forms another example of the increased chemical variation in southern european populations of common european lichens (cf. LeUCKERT \& POELT 1978).

\section{ACKNOWLEDGEMENTS}

Thanks are due to Prof. T. Ahti for valuable advice, to Mr. L. Y. Th. Westra for taking the photograph, and to the Beijerinck-Popping Fund for fieldwork support.

\section{REFERENCES}

Braun-Blanquet, J., A. R. Pinto da Silva \& A. Rozeira (1964): Résultats de trois excursions géobotaniques à travers le Portugal septentrional et moyen. III. Landes à cistes et éricacées (Cisto-Lavanduletea et Calluno-Ulicetea). Agronomia Lusitana 23: 229-313.

LeuckerT, Ch. \& J. POelt (1978): Ueber Nord-Süd-Gradienten von Chemotypen europäischer Flechten. Plant Systematics and Evolution 130: 53-77. 
SANDSTEDE, H. (1931): Die Gattung Cladonia, in: L. RABENHORST, Kryptogamenflora von Deutschlän, Oesterreich und der Schweiz, Aufl. 2, Bd. 9, Abt. 4, 2. Hälfte.

Thomson, J. W. (1967): The lichen genus Cladonia in North America. University of Toronto Press.

WALKER, F. J.\& P. W. JAmES (1980): A revised guide to microchemical techniques for the identification of lichen products. Bull. Brit. Lichen Soc. 46 (supplement): 13-29. 